\title{
About the Irish Universities Nutrition Alliance
}

The Irish Universities Nutrition Alliance (IUNA) is a formal association of the academic nutrition units at Trinity College Dublin, University College Cork and the
University of Ulster. The IUNA is committed to joint initiatives in research and teaching.

Further findings from the survey are available at the IUNA website: www.iuna.net

\section{Trinity College Dublin}

Department of Clinical Medicine Trinity Centre for Health Sciences St. James's Hospital

Dublin 8

Ireland

Tel: +353-1-6082101

Fax: +353-1-4542043

Email: mgibney@tcd.ie

\section{University College Cork}

Nutritional Sciences

Department of Food Science, Food

Technology and Nutrition

University College Cork

Cork

Ireland

Tel: +353-21-4902649

Fax: +353-21-4270244

email: a.flynn@ucc.ie

\section{University of Ulster}

Northern Ireland Centre for Diet and Health (NICHE)

University of Ulster

Coleraine BT52 1SA

Northern Ireland

Tel: +44-2870-324795

Fax: +44-2870-324965

email: jj.strain@ulst.ac.uk

\section{Funding}

Funding for this project was obtained from:

- The Department of Agriculture, Food and Rural Development in Dublin through the Non-Commissioned Food Research Programme, part financed by the European Regional Development Fund.

- The Food Safety Authority of Ireland, and its predecessor, the Food Safety Advisory Board.
- The Northern Ireland Centre for Diet and Health at the University of Ulster, assisted by the European Regional Development Fund through the IRTU Technology Development Programme.

- Industrial partners: Kelloggs, Bord Bhia, Coca-Cola, Cadburys, Dairy Council for Northern Ireland, Irish Sugar, Kerry Group, Mars Confectionery, Meat and Livestock Commission UK, National Dairy Council, Nestlé Ireland, Tesco Ireland and the Irish Business and Employers Confederation (IBEC). 